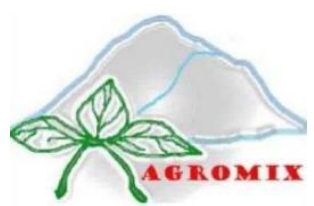

\title{
AGROMIX
}

Jurnal IImiah Fakultas Pertanian, Universitas Yudharta Pasuruan pISSN (Print): 2085-241X; elSSN (Online): 2599-3003

Website: https://jurnal.yudharta.ac.id/v2/index.php/agromix

\section{Analisis kelayakan finansial usaha beras aruk pada masa pandemi covid-19 (studi kasus: kelompok tani Sumber Jaya Desa Tempilang Kabupaten Bangka Barat)}

\author{
Analysis of the financial feasibility of aruk rice business during the covid-19 pandemic (case study: Sumber Jaya farmers \\ Group Tempilang Village, West Bangka Regency)
}

Eni Karsiningsih ${ }^{1^{*}}$

${ }^{1}$ Program Studi Agribisnis, Universitas Bangka Belitung, Balunijuk, Indonesia

*Email korespondensi: eni.karsiningsih02@gmail.com

\section{Article History \\ Received : August 5, 2021 \\ Accepted : September 15, 2021 \\ Published : September 28, 2021 \\ Keyword \\ Financial feasibility; aruk rice; analog rice; covid-19 pandemic}

\section{ABSTRACT}

Introduction: During the Covid-19 pandemic, aruk rice became one of the healthy alternative food additives for consumption. Aruk rice is a local food of cultural heritage for the people of Bangka Belitung that must be preserved. This study aims to analyze the financial feasibility of the aruk rice business during the Covid19 pandemic carried out by the Sumber Jaya Farmers Group, Tempilang Village, West Bangka Regency. Method: The research method used is a case study. Sampling was carried out by census, which took 8 aruk rice makers who produced during the Covid-19 pandemic. Analysis of the financial feasibility of aruk rice business is carried out by calculating NPV, Net B/C ratio, IRR, Payback Period, and BEP. Result: The results showed that during the Covid-19 pandemic, the aruk rice business provided a $12 \%$ higher profit, which was Rp. 866,700 per month compared to before the Covid-19 pandemic. Based on the financial feasibility analysis, the nasi aruk business during the Covid-19 pandemic is still feasible. Based on the results of the financial feasibility analysis at the interest rate of the BRI Micro KUR loan at $6 \%$ per year, the NPV value is Rp. $10,400,400$, Net B/C ratio is 1.5, IRR is $128 \%$, and the Payback Period or payback period. investment for 4 months 5 days. The aruk rice business will experience a Break Event Point when the income is IDR 218,200 per month, the production is $9 \mathrm{~kg}$ per month and the price is IDR 16,200 per kilo. Conclusion: Based on the results of the financial feasibility analysis, the rice aruk business conducted by the Sumber Jaya Farmers Group during the Covid-19 pandemic is still feasible.

\section{Riwayat Artikel}

Dikirim : 5 Agustus, 2021

Disetujui : 15 September, 2021

Diterbitkan : 28 September, 2021

\section{Kata Kunci}

Kelayakan finansial; beras aruk; beras analog; pandemi covid 19

\section{ABSTRAK}

Pendahuluan: Selama masa pandemi Covid-19 beras aruk menjadi salah satu makanan tambahan alternatif yang sehat untuk dikonsumsi. Beras aruk merupakan panganan lokal warisan budaya bagi masyarakat Bangka Belitung yang harus dilestarikan. Penelitian ini bertujuan untuk menganalisis kelayakan finansial usaha beras aruk selama masa pandemi Covid-19 yang dilakukan oleh Kelompok Tani Sumber Jaya Desa Tempilang Kabupaten Bangka Barat. Metode: Metode Penelitian yang digunakan adalah studi Kasus. Pengambilan sampel dilakukan secara sensus, yaitu mengambil 8 orang pembuat beras aruk yang melakukan produksi selama masa pandemi Covid-19. Analisis kelayakan finansial usaha beras aruk dilakukan dengan menghittung NPV, Net B/C ratio, IRR, Payback Period, dan BEP. Hasil: Hasil penelitian menunjukkan bahwa selama masa pandemi Covid-19, usaha beras aruk memberikan keuntungan $12 \%$ lebih tinggi yaitu sebesar yaitu Rp 866.700 per bulan dibandingkan sebelum terjadi pandemi Covid-19. Berdasarkan analisis kelayakan finansial, usaha beras aruk selama pandemi Covid-19 masih layak dilakukan. Berdasarkan hasil analisis kelayakan finansial pada tingkat suku bunga pinjaman KUR Mikro Bank BRI 6\% per tahun, maka diperoleh nilai NPV sebesar Rp 10.400.400, Net B/C ratio sebesar 1,5, IRR sebesar 128\%, dan Payback Period atau waktu pengembalian investasi selama 4 bulan 5 hari. Usaha beras aruk akan mengalami Break Event Point pada saat pendapatan sebesar Rp 218.200 per bulan, produksi $9 \mathrm{~kg}$ per bulan dan harga sebesar Rp 16.200 per kilo. Kesimpulan: Berdasarkan hasil analisis kelayakan finansial, usaha beras aruk yang dilakukan oleh Kelompok Tani Sumber Jaya selama pandemi Covid-19 masih layak dilakukan.

Sitasi: Karsiningsih, E. (2021). Analisis kelayakan finansial usaha beras aruk pada masa pandemi covid-19 (studi kasus: kelompok tani Sumber Jaya Desa Tempilang Kabupaten Bangka Barat). Agromix, 12(2), 22-32. https://doi.org/10.35891/agx.v12i2.2621

\section{PENDAHULUAN}

Corona Virus Disease 19 atau disebut juga Covid-19 merupakan virus yang berasal dari Wuhan Cina. Virus ini menyebar secara luas dan sangat cepat. Penyebaran virus ini memberikan dampak yang sangat signifikan bagi seluruh 
dunia tidak terkecuali Indonesia. Pandemi Covid-19 tidak hanya memberikan dampak yang besar bagi pemerintah tetapi juga berdampak signifikan bagi masyarakat (Suryani, 2021). Pandemi Covid-19 juga menimbulkan ketidakstabilan di semua sektor termasuk sektor pertanian ditinjau dari aspek agribisnis (Khairad, 2020). Pandemi Covid-19 menyebabkan ketersediaan pangan terganggu sehingga menimbulkan kerawanan pangan (Mardones dkk., 2020).

Selama masa pandemi Covid-19 beras aruk menjadi salah satu makanan tambahan alternatif yang sehat untuk dikonsumsi. Konsumsi beras aruk dapat menurunkan indeks masa tubuh dan persentase lemak tubuh seseorang lebih efektif dibandingkan konsumsi nasi putih (Arianti \& Oktarina, 2018). Beras aruk merupakan makanan yang terbuat dari ubi kayu yang telah mengalami fermentasi untuk diambil tepungnya dan diolah lebih lanjut menjadi butiran atau granula. Pada masa penjajahan, beras aruk pernah dijadikan sebagai makanan pokok pengganti beras (Setiati, 2008). Beras aruk merupakan warisan budaya lokal yang harus diperhatikan dan dijaga oleh masyarakat Bangka Belitung. Beras aruk merupakan salah satu makanan lokal berasal dari Provinsi Bangka Belitung yang keberadaannya harus dipertahankan dan dilestarikan (Subhan dkk., 2018). Berdasarkan uji Organoleptik banyak responden menyatakan suka saat mengkonsumsi beras aruk (Parwiyanti dkk., 2012). Hal ini menunjukkan indikasi bahwa niat mengkonsumsi beras aruk relatif tinggi.

Sebagai salah satu warisan budaya bagi masyarakat Bangka Belitung, keberadaan beras aruk sangat penting dan telah banyak dikaji oleh peneliti dari berbagai sudut pandang termasuk kajian sosial ekonomi. Selama pandemi Covid19 permintaan beras aruk cenderung meningkat. Akan tetapi tidak semua pembuat beras aruk yang tergabung dalam Kelompok Tani Sumber Jaya mau melakukan produksi. Isu penyebaran Virus Corona menyebabkan $50 \%$ pembuat beras aruk tidak mau melakukan produksi karena takut terinfeksi dan lebih memilih tidak banyak melakukan aktivitas untuk menjaga Kesehatan. Sedangkan 50\% tetap melakukan produksi beras aruk dengan alasan memenuhi permintaan pelanggan dan mengisi waktu luang di tengah pembatasan-pembatasan aktivitas yang ada.

Sebelum pandemi Covid-19 terjadi sudah dilakukan penelitian terhadap studi kelayakan usaha beras aruk. Hasil penelitian menunjukkan bahwa usaha beras aruk memberikan keuntungan sebesar Rp 773.200 per bulan. Berdasarkan analisis kelayakan finansial selama 5 tahun pada tingkat suku bunga pinjaman Bank BRI sebesar 12\% pertahun, usaha beras aruk layak dilakukan dengan nilai NPV sebesar Rp 47.779.017, Net B/C ratio sebesar 1,41, IRR sebesar 19\%, dan payback period selama 2 tahun 8 bulan 11 hari (Karsiningsih \& Pranoto, 2015). Akan tetapi penelitian ini belum menghitung kelayakan finansial usaha berdasarkan Break Event Point. Selain itu, adanya pandemic Covid-19 menyebabkan perubahan besaran biaya operasional seperti penambahan biaya untuk protokol Kesehatan dan biaya pemasaran yang cenderung meningkat terutama alokasi untuk pembelian kuota internet.

Selama pandemi Covid-19, permintaan terhadap beras aruk meningkat dengan mengedepankan isu Kesehatan. Selama pandemic Covid-19 konsumen cenderung memilih makanan yang segar, sehat dan aman (Leone dkk., 2020). Berdasarkan hasil penelitian sebelumnya dan adanya perubahan-perubahan yang terjadi akibat terjadinya pandemi Covid-19, maka kelayakan finansial usaha beras aruk harus dikaji lagi lebih mendalam dengan menambah kriteria kelayakan. Oleh karena itu, Urgensi penelitian ini adalah untuk melihat apakah selama pandemic Covid-19 usaha beras aruk ini masih memberikan keuntungan dan layak untuk diusahakan.

\section{METODE}

Metode yang digunakan dalam penelitian ini adalah studi kasus. Penelitian dilakukan pada Kelompok Tani Sumber Jaya di Desa Tempilang Kabupaten Bangka Barat dengan pertimbangan: 1) Selama pandemi Covid-19 masih melakukan produksi beras aruk 2) satu-satunya kelompok tani yang membuat beras aruk secara kontinu di Desa Tempilang. Adapun jumlah anggota Kelompok Tani Sumber Jaya adalah sebanyak 15 orang. Akan tetapi hanya 8 orang saja yang masih berproduksi selama masa pandemi Covid-19. Pengambilan sampel dilakukan secara sensus, artinya semua pembuat beras aruk yang masih beroperasi selama masa pandemi Covid-19 dijadikan responden penelitian. Waktu penelitian dilaksanakan mulai bulan Maret sampai dengan bulan April 2021.

Metode yang digunakan dalam menilai kelayakan finansial usaha beras aruk dianalisis menurut lima kriteria investasi yaitu analisis Net Present Value (NPV), Net B/C Ratio, Internal Rate of Return (IRR), Payback Period dan BEP (Dempu Salni dkk., 2019; Fitriani dkk., 2020; Jebrin, 2017; Karsiningsih, 2016; Patriawan dkk., 2018; Purnomo dkk., 2017; Syafril \& Fidhiani, 2020). Adapun rumus perhitungan yang digunakan adalah sebagai berikut:

\section{Net present value (NPV)}

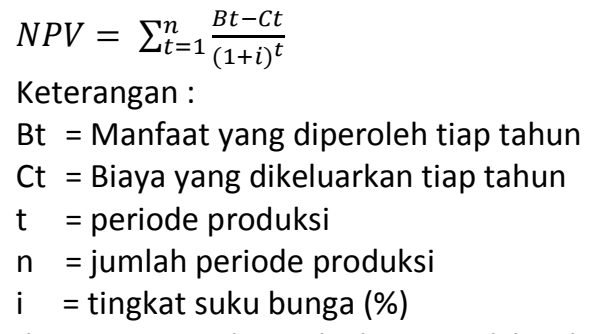

Jika NPV $>0$, maka usaha beras aruk layak dilakukan. Jika NPV $<0$, maka usaha beras aruk tidak layak untuk dilakukan. 


\section{Net B/C Ratio}

Net $B / C$ Ratio $=\frac{\sum P . V . \text { net } B \text { yang positif }}{\sum P . V . \text { net } B \text { yang negatif }}=\frac{\text { net } B}{\text { net } C}$

Jika Net B/C Ratio > 1 maka usaha beras aruk layak dilakukan. Jika Net B/C Ratio $<1$ maka usaha beras aruk tidak layak dilakukan.

\section{Internal rate of return (IRR)}

$$
I R R=i^{1}+\frac{N P V^{1}}{\left(N P V^{1}-N P V^{2}\right)} \quad\left(i^{2}-i^{1}\right)
$$

Keterangan :

$\mathrm{i}^{1}=$ adalah tingkat discout rate yang menghasilkan NPV ${ }^{1}$

$\mathrm{i}^{2}$ = adalah tingkat discout rate yang menghasilkan NPV ${ }^{2}$

Jika IRR>opportunity cost of capital (OCC), maka usaha beras aruk layak dilakukan. Jika IRR<opportunity cost of capital (OCC), maka usaha beras aruk tidak layak dilakukan.

\section{Payback period (PP)}

Payback Period $=n+\frac{a-b}{c-b} \times 1$ tahun

Keterangan :

$\mathrm{n}=$ tahun terakhir di mana jumlah cash flow masih belum bisa menutup investasi

a = jumlah original investment

$\mathrm{b}=$ jumlah kumulatif cash flow pada tahun ke $\mathrm{n}$

$c=$ jumlah kumulatif cash flow pada tahun ke $\mathrm{n}+1$

usaha pembuatan beras aruk layak dilakukan jika masa pengembalian lebih cepat dari umur investasi. Sebaliknya, usaha beras aruk tidak layak dilakukan jika masa pengembalian lebih lama dari umur investasi, artinya usaha tersebut tidak mampu mengembalikan biaya yang telah dikeluarkan.

\section{Break event point (BEP)}

Analisis BEP (titik impas) dapat dibagi menjadi 2 yaitu BEP dalam satuan penjualan dan BEP dalam satuan unit produksi (Halim, 2011). Secara rinci dapat dirumuskan sebagai berikut:

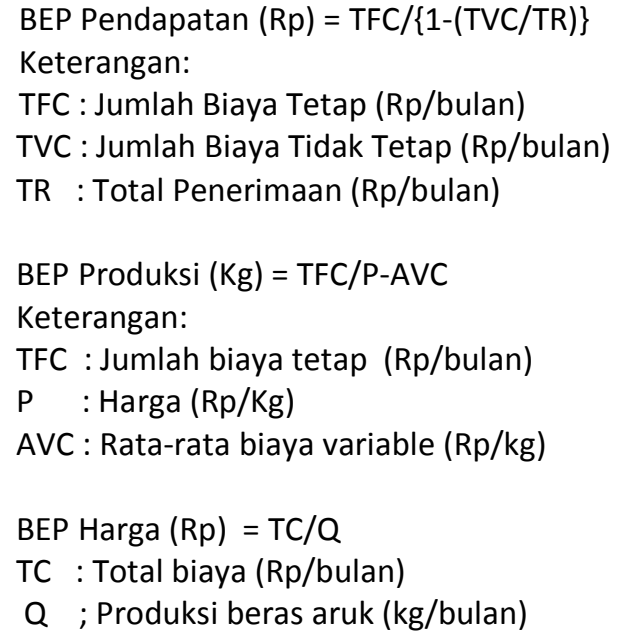

HASIL DAN PEMBAHASAN

\section{Proses pengolahan beras aruk}

Selama masa pandemi covid-19, Kelompok Tani Sumber Jaya merupakan salah satu kelompok tani pengolah beras aruk yang masih bertahan sampai hari ini di Desa Tempilang Kabupaten Bangka Barat. Tujuan utama kelompok tani ini masih kontinu memproduksi beras aruk lebih ditekankan pada pelestarian nilai budaya. Sampai saat ini budaya makan beras aruk masih menjadi sebuah tradisi atau kebiasaan masyarakat Desa Tempilang. Disamping itu, mereka harus 
memenuhi permintaan pelanggan yang kontinu mengkonsumsi beras aruk tersebut. Bahkan mereka harus mengirim beras aruk tersebut kepada pelanggan mereka yang berada di Jakarta.

Selama masa pandemi covid-19, permintaan masyarakat terhadap beras aruk cenderung meningkat. Beras aruk biasanya dijadikan makanan pelengkap saja atau camilan. Beras aruk bisa diolah lebih lanjut menjadi aneka makanan seperti kue dan nasi goreng (Subhan dkk., 2018), nasi aruk isi ikan, nasi aruk gulung isi dan aneka makanan lainnya. Permintaan beras aruk paling tinggi berasal dari kelompok orang yang mengkonsumsi beras aruk karena alasan historis yaitu sebesar $57 \%$. Kelompok ini menyatakan bahwa mereka mengkonsumsi beras aruk karena sudah terbiasa dan telah dilakukan secara turun temurun sejak zaman penjajahan. Berikutnya, $40 \%$ permintaan beras aruk beras aruk berasal dari kelompok orang yang mengkonsumsi beras aruk karena alasan Kesehatan dan mempunyai penyakit seperti diabetes, jantung, obesitas dan lain sebagainya. kelompok ini menyatakan bahwa mereka merasa tubuhnya lebih sehat saat mengkonsumsi beras aruk. hal ini disebabkan beras aruk memiliki kadar gula yang rendah dan memiliki serat pangan tinggi. Kandungan karbohidrat dalam beras aruk bisa diubah menjadi sumber energi bagi orang-orang yang menderita penyakit diabetes (Mahdi dkk., 2018). Sisanya 3\% dikonsumsi oleh orang-orang yang baru mencoba makan beras aruk. Kelompok ini biasanya memperoleh beras aruk sebagai souvenir. Selain itu, mereka makan beras aruk dengan alasan unik dan makanan tradisional.

Proses pembuatan beras aruk dilakukan secara tradisional dan turun temurun. Proses pembuatan beras aruk mulai dari menyediakan bahan baku sampai beras aruk siap jual memerlukan waktu yang cukup lama \pm 1 minggu. Adapun proses pengolahan beras aruk dapat dilakukan melalui beberapa tahap, yaitu:

\section{Mempersiapkan bahan baku}

Bahan baku utama pembuatan beras aruk adalah ubi kayu. Ubi kayu yang digunakan harus memiliki kualitas yang baik seperti segar, umbinya tidak rusak dan berumur sekitar 1 tahun. Umur panen ubi kayu yang banyak mengandung pati berkisar antara 9-12 bulan. Akan tetapi indeks panen ubi kayu yang paling baik dengan kandungan pati tertinggi adalah 1 tahun atau 12 bulan (Apea-Bah dkk., 2011; Moorthy \& Ramanujam, 1986; Puspitorini dkk., 2016; Susilawati, 2010). Jika ubi kayu yang digunakan kurang dari 1 tahun, biasanya akan menyebabkan beras aruk yang dihasilkan lebih sedikit karena belum banyak memiliki pati atau kandungan tepung. Sedangkan jika ubi kayu terlalu tua akan menyebabkan kadar pati juga sedikit. Aksesi ubi kayu yang biasa digunakan untuk pembuatan beras aruk adalah ubi kayu aksesi batin, aksesi mentega dan aksesi pulut/ketan. Produksi beras aruk tertinggi dihasilkan oleh aksesi sutera sebesar 773,13 gram/tanaman (Lestari, 2014). Akan tetapi pembuat beras aruk sangat jarang menggunakan aksesi sutera karena tidak terbiasa. Guna memenuhi kebutuhan ubi kayu sebagai bahan baku dalam pembuatan beras aruk, Kelompok Tani Sumber Jaya menanam sendiri ubi kayu tersebut. Jika permintaan beras aruk meningkat dan ketersediaan bahan baku tidak mencukupi, mereka membeli ubi kayu langsung dari petani ubi kayu yang sudah mereka percaya. Hal ini mereka lakukan untuk menjamin bahan baku yang mereka gunakan berkualitas baik.

\section{Pengupasan}

Pengupasan ubi kayu dilakukan untuk membuang bagian kulit luar. Pengupasan ubi kayu dilakukan dengan cara membuang kulit luar ubi kayu dengan pisau, kemudian tarik kulit luar ubi kayu dengan tangan agar lapisan kambium tidak rusak. Ubi kayu yang telah dikupas akan dimasukkan ke dalam ember atau baskom besar. Hasil penelitian menunjukkan bahwa ubi kayu yang telah dikupas mengalami penyusutan sebesar 28,5 persen dari berat semula. Setiap $100 \mathrm{~kg}$ ubi kayu akan menghasilkan 71,5 kg ubi kayu segar kupas.

\section{Pencucian}

Setelah ubi kayu selesai dikupas akan dilanjutkan ke tahap pencucian. Ubi kayu yang telah dikupas dimasukkan ke dalam wadah (ember atau baskom) dan dicuci dengan menggunakan air. Ubi kayu sebaiknya dicuci pada air yang mengalir. Pencucian ubi kayu dimaksudkan untuk membersihkan ubi kayu dari kotoran atau benda lain. Hal ini dilakukan agar kualitas beras aruk yang dihasilkan baik, bersih dan hygenis. Agar ubi kayu benar-benar bersih para pembuat beras aruk menyikat ubi kayu dengan menggunakan sabut kelapa.

\section{Perendaman}

Ubi kayu yang telah dicuci bersih, selanjutnya akan direndam dalam drum plastik besar selama 4 hari. Perendaman dilakukan agar ubi kayu mengalami proses fermentasi. Proses fermentasi diharapkan dapat mengubah tekstur ubi kayu menjadi lebih lembut sekaligus menghilangkan kadar sianida. Dalam proses pembuatan beras aruk, Hidrogen Sianida (HCN) atau asam sianida mempunyai kadar terendah pada saat direndam selama tiga hari (Yudi Garnida, 2014). Adapun perendaman selama 4 hari semakin membuat asam sianida semakin hilang.

\section{Pengambilan Tepung}

Ubi kayu yang telah direndam selama 4 hari akan menjadi lunak dan siap untuk diambil patinya atau tepungnya. Proses ini dimulai dengan membuang sisa air rendaman ubi kayu terlebih dahulu. Kemudian ubi kayu yang telah difermentasikan akan dihancurkan dan dibuang empulurnya dengan cara diremas-remas menggunakan tangan dalam saringan di dalam baskom besar yang berisi air bersih. Hal ini dilakukan agar pati ubi kayu dapat larut dalam air. 
Kemudian air yang telah bercampur dengan pati ubi kayu akan dimasukkan ke dalam karung dari bahan kain untuk selanjutnya masuk ke tahap pengepresan. Pati dari ubi kayu yang dihasilkan menjadi bahan utama dalam pembuatan beras aruk.

\section{Pengepresan Pertama}

Langkah selanjutnya adalah melakukan pengepresan pertama. Pati ubi kayu yang sudah dimasukkan ke dalam karung berbahan kain akan dipres menggunakan alat pengapit selama \pm 30 menit guna mengurangi kadar air. Secara tradisional pembuat beras aruk di Desa Tempilang menggunakan alat pengapit yang sederhana yaitu jerigen ukuran 40 liter yang diisi air. Jerigen tersebut akan berfungsi sebagai alat pemberat yang berguna dalam proses pengepresan. Tepung yang dihasilkan pada proses pengepresan pertama dikeluarkan dari karung berbahan kain untuk selanjutnya masuk ke proses penumbukan.

\section{Penumbukan}

Setelah proses pengepresan pertama dilakukan, dilanjutkan dengan proses penumbukan terhadap tepung ubi kayu yang dihasilkan. Penumbukan dilakukan dengan maksud agar tepung menjadi lebih halus. Penumbukan dilakukan dengan cara memasukkan tepung yang sudah dipres ke dalam alat penumbuk tradisional yang disebut Lesung dan ditumbuk menggunakan alu yang bersih. Proses penumbukan dengan menggunakan lesung akan mempengaruhi rasa khas dari beras aruk menjadi lebih enak.

\section{Pengepresan Kedua}

Tahap selanjutnya adalah melakukan pengepresan kedua. Pengepresan kedua dilakukan dengan cara memasukkan tepung yang sudah ditumbuk ke dalam karung berbahan kain dan dilanjutkan dengan pengepresan kedua dengan pengapit sederhana selama \pm 30 menit. Pengepresan kedua dilakukan dengan maksud menghilangkan kadar air yang masih terkandung dalam tepung. Hal ini dilakukan agar pada saat pembentukan butiran-butiran beras aruk mudah dilakukan dan kualitas beras aruk yang dihasilkan baik.

\section{Pembentukan Butiran}

Tahap selanjutnya, tepung ubi kayu yang telah dipres kedua akan diayak menggunakan ayakan yang terbuat dari alumunium. Agar diperoleh beras aruk yang berbentuk butiran (granula), maka tepung yang telah diletakkan di atas ayakan akan diputar-putar menggunakan tangan. kemudian tepung ubi kayu yang telah diayak akan dibentuk bulatan sempurna dengan cara membentuk bulatan dengan tangan di atas tikar Mengkuang. Tikar Mengkuang merupakan tikar yang terbuat dari daun Mengkoang. Tikar ini biasa digunakan untuk keperluan sehari hari dengan desain anyaman yang kreatif dan unik dan mencerminkan keaslian budaya melayu (Ismail dkk., 2013). Agar butiran terbentuk dengan ukuran yang sama maka gerakan tangan harus seirama dengan gesekan daun mengkoang. Tikar tradisional ini akan menentukan kualitas beras aruk karena menyebabkan keseragaman ukuran dalam proses pembentukan butiran-butiran beras aruk.

\section{Penyangraian}

Beras aruk yang telah terbentuk menjadi butiran-butiran akan disangrai dengan api kecil. Hal ini dilakukan dengan cara menyiapkan kuali berukuran besar dan bersih, kemudian dioles dengan minyak goreng. Minyak goreng berfungsi untuk membuat beras aruk tidak lengket saat disangrai. Selanjutnya beras aruk dituangkan dalam kuali untuk disangrai selama \pm 45 menit. Proses penyangraian ini dilakukan untuk menghilangkan kadar air yang masih tersisa serta memisahkan butiran-butiran agar tidak melekat satu sama lain. Beras aruk dikatakan sudah matang jika butiran-butiran sudah berubah warna menjadi bening.

\section{Pengeringan}

Setelah proses penyangraian selesai, dilanjutkan ke tahap pengeringan. Pengeringan dilakukan secara alami dengan melakukan penjemuran di bawah sinar matahari. Proses ini dilakukan agar kadar air dalam beras aruk benar-benar hilang sehingga beras aruk yang dihasilkan dapat tahan lama. Umur simpan beras aruk bisa mencapai kurang lebih 2 tahun. Beras aruk akan dijemur di atas para-para dengan menggunakan terpal ukuran $2 \times 3$ meter. Adapun para-para berukuran panjang 3,2 meter, lebar 1,5 meter dan tinggi 1,5 meter. Normalnya, Pengeringan dilakukan selama 2 hari. Akan tetapi jika cuaca kurang baik akan membutuhkan waktu yang lebih lama. Proses Pengeringan sangat penting dalam meningkatkan ketahanan beras aruk. Pengeringan dapat mencegah pertumbuhan dan reproduksi proliferasi mikroba, mengurangi reaksi biokimia yang memburuk akibat kelembaban sehingga dapat memperpanjang umur simpan produk dan meningkatkan nilai tambah (Xiao \& Mujumdar, 2020).

\section{Pengemasan}

Setelah beras aruk betul-betul kering, beras aruk akan dikemas ke dalam kantong plastik ukuran 1 kg dan dimasukkan ke dalam kotak yang telah diberi merek. Pengemasan dilakukan agar produk lebih menarik dan memudahkan dalam pemasaran sehingga beras aruk memiliki nilai jual yang lebih tinggi. Kemasan suatu produk sangat mempengaruhi niat beli konsumen (Yeo dkk., 2020). Dalam agribisnis produk pertanian fungsi kemasan tidak hanya melindungi, tetapi 
kemasan juga bisa memberi daya tarik, menyediakan informasi produk, membangun citra dan kesadaran merek (Kwaku \& Fan, 2020). Merek beras aruk yang diproduksi oleh Kelompok Tani Sumber Jaya Desa Tempilang adalah "Beras Ubi (Aruk) Kelompok Tani Sumber Jaya". Pemberian merek dilakukan agar produk tersebut mudah untuk dikenali sebagai salah satu produk unggulan Desa Tempilang. Dalam strategi pemasaran produk, merek yang bersifat lokal mendapat respon yang positif dari konsumen dan berpengaruh signifikan bagi kinerja penjualan (Hoskins dkk., 2021). Beras aruk produksi kelompok Tani Sumber Jaya dikemas dengan menggunakan kotak kemasan yang sudah diberi merek dengan isi bersih 1 kilogram per kotak.

\section{Keuntungan usaha beras aruk}

Selama masa pandemi covid-19, usaha pengolahan beras aruk memberikan keuntungan cenderung meningkat. Keuntungan yang diperoleh tidak besar dan sedikit lebih tinggi dibandingkan keuntungan sebelum terjadi pandemi covid-19 yaitu Rp 773.200 per bulan (Karsiningsih \& Pranoto, 2015). Selama pandemi covid 19, permintaan beras aruk relatif meningkat. Aktivitas sosial ekonomi masyarakat yang terjadi di Desa Tempilang tidak banyak berubah. Sedangkan di wilayah lain pandemi covid-19 menyebabkan lockdown dan menyebabkan kerentanan kondisi sosial-ekonomi yang parah di kalangan pekerja industri rumah tangga (Rahaman \& Khatun, 2021). Masyarakat Desa Tempilang melakukan aktivitas kehidupan sehari-hari seperti biasa dan mereka membatasi orang luar desa masuk ke desa agar penyebaran virus covid-19 bisa dihambat. Sementara di tempat lain, banyak masyarakat yang mengeluh karena aktivitas mereka terhenti akibat adanya pembatasan-pembatasan sehingga berdampak signifikan terhadap keadaan ekonomi keluarga (PH dkk., 2020). Pendapatan yang diperoleh dari usaha pengolahan beras aruk memberikan kontribusi sebesar 21,7 persen terhadap total pendapatan keluarga. Rata-rata pendapatan keluarga yang diperoleh dari luar usaha beras aruk adalah sebesar Rp 4.000.000 per bulan. selain itu, kegiatan pembuatan beras aruk memberikan dampak sosial yang positif khususnya kepada para ibu-ibu rumah tangga dalam mengisi waktu luang mereka.

Dalam penelitian ini, biaya yang dikeluarkan terdiri dari biaya tetap dan biaya variable. Secara rinci dapat dilihat pada tabel 1.

Tabel 1. Total biaya usaha pengolahan beras aruk per bulan ( $\mathrm{Rp} / \mathrm{bulan})$

\begin{tabular}{lrr}
\hline \multicolumn{1}{c}{ Uraian } & Nilai (Rp) & Persentase (\%) \\
\hline A. Biaya Tetap & & 0,36 \\
Penyusutan alat & 5.800 & 3,06 \\
Bangunan Produksi & 50.000 & 3,42 \\
Total biaya tetap & 55.800 & \\
B. Biaya Variabel & & 48,98 \\
Ubi kayu & 800.000 & 1,84 \\
Minyak tanah & 30.000 & 0,46 \\
Minyak goreng & 7.500 & 12,25 \\
Kotak kemasan & 200.000 & 30,61 \\
Tenaga Kerja & 500.000 & 1,22 \\
Transportasi & 20.000 & 1,27 \\
Kuota internet & 20.000 & 96,58 \\
Total biaya variabel & 1.577 .500 & 100 \\
\hline C. Total Biaya & 1.633 .300 & \\
\hline Sumbr: Data primer
\end{tabular}

Sumber: Data primer diolah (2021)

Tabel 1 menunjukkan bahwa total biaya yang dikeluarkan untuk mengolah beras aruk adalah sebesar Rp 1.633 .300 per bulan. Pengeluaran terbesar berasal dari komponen biaya variable yaitu sebesar 96,58 persen. Sedangkan biaya tetap hanya sebesar 3,42 persen. Kecilnya komponen biaya tetap dari penyusutan alat disebabkan peralatan yang digunakan dalam pengolahan beras aruk masih bersifat sangat tradisional. Usaha pengolahan beras aruk hanya dijadikan sebagai pekerjaan sampingan saja. Biaya bahan baku dan biaya tenaga kerja merupakan komponen biaya terbesar dalam usaha pembuatan beras aruk. Biaya bahan baku dan tenaga kerja dapat meningkatkan volume penjualan (Anggraeni dkk., 2020). Komponen biaya bahan baku dan tenaga kerja berpengaruh signifikan terhadap penjualan bersih suatu produk (Sugiarti, 2018). Pada usaha beras aruk, Biaya variable terbesar berasal dari bahan baku yaitu pengeluaran untuk membeli ubi kayu. Pengeluaran ini hampir mencapai setengah dari total biaya yang dikeluarkan yaitu 48,98 persen. Perbandingan ubi kayu sebagai bahan baku dengan beras aruk yang dihasilkan adalah 4:1. Artinya setiap 100 kg ubi kayu yang diolah akan menghasilkan $25 \mathrm{~kg}$ beras aruk. Biaya bahan baku berpengaruh positif terhadap penjualan produk (Juwita \& Puspita, 2021). Selain itu, pengeluaran biaya variable yang terbesar kedua berasal dari upah tenaga kerja yang dikeluarkan. Rata-rata jumlah tenaga kerja yang digunakan untuk pengolahan beras aruk sebanyak 2 orang. Rata-rata upah tenaga kerja yang dikeluarkan untuk dua orang pekerja sebesar Rp 125.000 per satu kali produksi. Biasanya tenaga kerja yang mereka gunakan untuk membantu dalam mengolah beras aruk masih ada hubungan kekerabatan atau keluarga. 
Dalam melakukan usaha beras aruk, Kelompok Tani Sumber Jaya memiliki kendala utama yaitu ketersediaan rumah produksi. Selama ini mereka melakukan produksi di rumah mereka masing-masing dengan memanfaatkan dapur yang ada. Padahal proses pengolahan beras aruk ini memerlukan tempat khusus yang terpisah dari rumah karena ada limbah dari perendaman yang mengeluarkan bau kurang sedap saat proses fermentasi. Sehingga sebaiknya proses pembuatan beras aruk memiliki rumah produksi sendiri. Pada tahun 2017 Kelompok Tani Sumber Jaya ini mendapat bantuan peralatan yang lengkap dari pemerintah pusat. Peralatan ini memiliki teknologi yang relatif tinggi seperti mesin penumbuk, mesin pengepress, mesin pembuat granula. Akan tetapi mesin-mesin tersebut belum bisa mereka gunakan karena belum tersedia rumah produksi yang permanen. Mesin-mesin bantuan tersebut belum pernah digunakan dan hanya tersimpan di rumah ketua kelompok tani saja. Kelompok Tani Sumber Jaya berharap agar usaha mereka bisa berkembang dan bersifat lebih komersial dalam skala besar dengan memanfaatkan sumberdaya yang mereka miliki. Sehingga mereka sangat berharap pemerintah daerah dapat memberikan bantuan dengan membangun rumah produksi yang standar.

Rata-rata penerimaan yang mereka peroleh dari usaha beras aruk adalah $\mathrm{Rp} 2.500 .000$ per bulan dengan rata-rata produksi sebesar $100 \mathrm{~kg}$ beras aruk dan harga Rp 2.5000 per kilogram. Sehingga keuntungan yang mereka peroleh sebesar Rp 866.700 perbulan. Keuntungan ini meningkat 12\% dibandingkan sebelum terjadi pendemi Covid-19. Walaupun keuntungan yang diperoleh dari usaha pengolahan beras aruk ini tidak begitu besar, tetapi secara sosial mampu menyerap tenaga kerja sehingga bisa membantu perekonomian keluarga. Selain itu, usaha beras aruk bisa melestarikan budaya makanan tradisional masyarakat Bangka Belitung sebagai salah satu bentuk kearifan lokal yang harus dipertahankan.

Tabel 2. Keuntungan usaha beras aruk per bulan (Rp/bulan)

\begin{tabular}{|c|c|}
\hline Uraian & Nilai (Rp) \\
\hline Total Biaya & 1.633 .300 \\
\hline Produksi beras aruk & 100 \\
\hline Harga & 25.000 \\
\hline Total Penerimaan & 2.500 .000 \\
\hline Keuntungan & 866.700 \\
\hline
\end{tabular}

Sumber: Data primer diolah (2021)

\section{Analisis finansial usaha beras aruk}

Dalam penelitian ini, perhitungan Analisis finansial usaha beras aruk selama masa pandemi covid-19 menggunakan beberapa asumsi:

1. Periode analisis finansial usaha beras aruk dilakukan selama 12 bulan.

2. Data yang digunakan untuk perhitungan analisa usaha beras aruk adalah data dari bulan April 2020 sampai dengan bulan Maret 2021. Adapun Produksi beras aruk dilakukan 4 kali per bulan.

3. Tingkat suku bunga yang digunakan mengacu pada suku bunga pinjaman KUR Mikro Bank BRI yaitu 6\% per tahun.

Hasil penelitian menunjukkan bahwa berdasarkan analisis kelayakan finansial selama masa pandemi covid-19, usaha beras aruk masih layak untuk dilakukan. Secara rinci kriteria kelayakan usaha beras aruk dapat dilihat pada tabel 3.

Tabel 3. Analisis kelayakan finansial usaha beras aruk selama masa pandemi covid-19 dalam kurun waktu 12 bulan

\begin{tabular}{clrc}
\hline No & \multicolumn{1}{c}{ Kriteria } & Hasil & Keterangan \\
\hline 1 & NPV & Rp 10.400.400 & Layak \\
2 & Net B/C Ratio & 1,5 & Layak \\
3 & IRR & $128 \%$ & Layak \\
4 & Payback Period & 4 bulan 5 hari & Layak \\
5 & BEP Pendapatan & Rp 218.200 per bulan & Layak \\
6 & BEP Produksi & 9 kg per bulan & Layak \\
7 & BEP Harga & Rp 16.200 per kilo & Layak \\
\hline
\end{tabular}

Sumber: Data Primer Diolah (2021)

Tabel 3 menunjukkan bahwa berdasarkan kriteria kelayakan finansial, usaha beras aruk yang dilakukan oleh Kelompok Tani Sumber Jaya selama masa pandemi covid-19 masih layak diusahakan. Berdasarkan hasil perhitungan yang telah dilakukan, diperoleh nilai NPV sebesar Rp 10.400.400. Nilai ini menunjukkan bahwa usaha beras aruk layak dilakukan karena NPV lebih besar dari 0. NPV merupakan kriteria terbaik dan penting dalam menilai keberhasilan suatu usaha (Pasqual dkk., 2013; Smith-Daniels \& Aquilano, 1987). Dalam penelitian ini, Perhitungan NPV riil dilakukan berdasarkan data yang diperoleh dari lapangan. NPV juga bisa digunakan untuk menilai usaha atau proyek dalam ketidakpastian yang diprediksi di masa depan (Gaspars-Wieloch, 2019).

Usaha pengolahan beras aruk menghasilkan nilai $\mathrm{Net} B / C$ ratio sebesar 1,5 . Artinya benefit yang diterima oleh pengolah beras aruk 1,5 kali lipat dibandingkan dengan biaya yang telah dikeluarkan. Usaha beras aruk layak dilakukan karena net $B / C$ ratio lebih besar dari 1 . Net $B / C$ ratio merupakan kriteria umum yang sering digunakan untuk menilai 
manfaat suatu usaha (Tung, 1992). Penelitian ini sejalan dengan Saini dkk. (2021) yang menyatakan bahwa selama masa pandemi covid-19, nilai B/C ratio bisa mencapai lebih dari 1 sehingga suatu usaha layak untuk dilanjutkan.

Adapun nilai IRR sebesar $128 \%$ menunjukkan bahwa usaha pengolahan beras aruk yang dilakukan oleh Kelompok Tani Sumber Jaya layak diusahakan karena nilai IRR 128\% lebih besar dari tingkat suku bunga pinjaman KUR Mikro Bank BRI 6\% per tahun. Analisis IRR dapat digunakan untuk mengambil keputusan dari aspek ekonomi pada suatu usaha makanan (Han, 2012).

Berdasarkan hasil perhitungan, nilai Payback Period usaha beras aruk selama pandemi Covid-19 adalah 4,16. Hal ini menunjukkan bahwa selama masa pandemi Covid 19 waktu pengembalian investasi usaha beras aruk tergolong relative cepat yaitu selama 4 bulan 5 hari. Waktu pengembalian investasi menunjukkan bahwa usaha beras aruk selama pandemi Covid-19 layak dilakukan karena nilai Payback Period lebih rendah dari waktu penilaian investasi yaitu selama 12 bulan.

Berdasarkan analisis Break Event Point (BEP), usaha beras aruk memiliki nilai lebih besar dari BEP Pendapatan, BEP Produksi, dan BEP harga sehingga usaha beras aruk layak untuk diusahakan. Nilai BEP Pendapatan sebesar Rp 218.200 per bulan, BEP produksi sebanyak $9 \mathrm{Kg}$ per bulan, dan BEP harga sebesar Rp 16.200 per bulan. Kenyataannya, selama masa pandemi Covid-19, para pembuat beras aruk memperoleh penerimaan sebesar Rp 2.500 .000 per bulan dan produksi beras aruk sebanyak $100 \mathrm{~kg}$ per bulan dengan harga jual sebesar Rp 25.000 per bulan. Harga produk dan biaya berpengaruh paling signifikan terhadap kelayakan usaha makanan (Han, 2012).

\section{KESIMPULAN}

Hasil penelitian menunjukkan bahwa selama masa pandemi Covid-19, usaha beras aruk memberikan keuntungan $12 \%$ lebih tinggi yaitu sebesar yaitu Rp 866.700 per bulan dibandingkan sebelum terjadi pandemi Covid-19. Berdasarkan hasil analisis kelayakan finansial pada tingkat suku bunga pinjaman KUR Mikro Bank BRI 6\% per tahun, maka diperoleh nilai NPV sebesar Rp 10.400.400, Net B/C ratio sebesar 1,5, IRR sebesar 128\%, dan Payback Period atau waktu pengembalian investasi selama 4 bulan 5 hari. Usaha beras aruk akan mengalami Break Event Point pada saat pendapatan sebesar Rp 218.200 per bulan, produksi 9 kg per bulan dan harga sebesar Rp 16.200 per kilo. Hasil ini menunjukkan bahwa berdasarkan analisis kelayakan finansial, usaha beras aruk selama masa pandemi Covid-19 masih layak dilakukan.

\section{UCAPAN TERIMA KASIH}

Terima kasih penulis sampaikan kepada Universitas Bangka Belitung yang telah memfasilitasi pelaksanaan penelitian dan Jurusan Agribinis UBB yang telah memberikan bantuan biaya publikasi hasil penelitian.

\section{DAFTAR PUSTAKA}

Anggraeni, I., Priatna, H., \& Madaniah, D. (2020). Pengaruh biaya bahan baku dan biaya tenaga kerja terhadap volume produksi pada CV Ismaya Citra Utama. Jurnal IImiah Akuntansi, 11(2), 22-32. https://www.ejournal. unibba.ac.id/index.php/akurat/article/view/312/270

Apea-Bah, F. ., Oduro, I., Ellis, W. O., \& Safo-Kantanka, O. (2011). Factor analysis and age at harvest effect on the quality of flour from four cassava varieties. American-Eurasian J. Agric. \& Environ. Sci., 11(3), 326-333. https://doi.org/10.1002/star.19860380206

Arianti, R., \& Oktarina, O. (2018). The benefit of purple aruk rice (siangu) in lowering Body Mass Index (BMI) and Body fat percentage. Scientiae Educatia, 7(1), 21-32. https://doi.org/10.24235/sc.educatia.v7i1.1885

Dempu Salni, Abdi, \& Yusran. (2019). Analisis kelayakan finansial usaha pengolahan jagung pada rumah tangga tani di Desa Mantobua Kecamatan Lohia Kabupaten Muna. Jurnal Agribisnis Dan IImu Sosial Ekonomi Pertanian, 4(3), 5760. https://doi.org/http://dx.doi.org/10.33772/jia.v4i3.7904

Fitriani, Arifin, B., Abbas Zakaria, W., Hanung Ismono, R., \& Erry Prasmatiwi, F. (2020). Sustainable production of lampung robusta coffee: a cost-benefit analysis. International Journal of Ecology and Development, 35(1). www.ceserp.com/cp-jour

Gaspars-Wieloch, H. (2019). Project net present value estimation under uncertainty. Central European Journal of Operations Research, 27(1), 179-197. https://doi.org/10.1007/s10100-017-0500-0

Halim, A. (2011). Analisis investasi edisi kedua. Jakarta: Salemba Empat.

Han, D. H. (2012). The economic analysis of feasibility study on the food factories of Egypt. Communications in Computer and Information Science, 340 CCIS, 353-360. https://doi.org/10.1007/978-3-642-35267-6_47

Hoskins, J., Verhaal, J. C., \& Griffin, A. (2021). How within-country consumer product (or brand) localness and supporting marketing tactics influence sales performance. European Journal of Marketing, 55(2), 565-592. https://doi.org/10.1108/EJM-11-2018-0787

Ismail, N. H., Md Nawawi, N., Leng, N. K., \& Muhazer, H. S. (2013). The art of Melaka: Mengkuang plaiting. Academia Journal UiTMT, 2(3), 94-99. http://journale-academiauitmt.edu.my/ 
Jebrin, A. (2017). The theoretical strategic approach in the feasibility study. Journal of Economics, Management and Trade, 19(2), 1-14. https://doi.org/10.9734/jemt/2017/36268

Juwita, R., \& Puspita, A. R. (2021). Pengaruh biaya bahan baku terhadap penjualan bersih pada PT Indofood CBP Sukses Makmur Tbk. Land Journal, 2(1), 23-32. https://doi.org/10.47491/landjournal.v2i1.1035

Karsiningsih, E. (2016). Analisis kelayakan finansial dan strategi pengembangan teh gaharu di Kabupaten Bangka Tengah (Studi Kasus: Teh Gaharu "Aqilla" Gapoktan Alam Jaya Lestari). AGRARIS: Journal of Agribusiness and Rural Development Research, 143-151. https://doi.org/10.18196/agr.2235

Karsiningsih, E., \& Pranoto, Y. S. (2015). Analisis komparatif proses produksi dan kelayakan beras aruk tradisional dan beras aruk dengan penambahan starter di Desa Tempilang Kabupaten Bangka Barat. 2015. http://repository.ubb.ac.id/1723/

Khairad, F. (2020). Sektor pertanian di tengah pandemi covid-19 ditinjau dari aspek agribisnis. Jounal Agriuma, 2(2), 8289. http://www.ojs.uma.ac.id/index.php/agriuma/article/view/4357

Kwaku, A. R., \& Fan, Q. (2020). Effect of good product design and packaging on market value and the performance of agricultural products in the Ghanaian Market. Open Access Library Journal, 07(09), 1-14. https://doi.org/10.4236/oalib.1106714

Leone, L. A., Fleischhacker, S., Anderson-Steeves, B., Harper, K., Winkler, M., Racine, E., Baquero, B., \& Gittelsohn, J. (2020). Healthy food retail during the covid-19 pandemic: Challenges and future directions. International Journal of Environmental Research and Public Health, 17(20), 1-14. https://doi.org/10.3390/ijerph17207397

Lestari, T. (2014). Pelestarian plasma nutfah ubi kayu lokal bangka sebagai diversifikasi pangan lokal. Enviagro: Jurnal Pertanian dan Lingkungan, 7(2), 1-6.

Mahdi, Rosa, F., Saparin, \& Sari Wijianti, E. (2018). Rancang bangun mesin penumbuk sagu ubi kayu untuk proses pembuatan beras aruk dengan motor listrik 0,5 Hp. Jurnal Teknik Mesin, 1(1), $13-17$. http://dx.doi.org/10.36767\%2Fturbulen.v1i1.344

Mardones, F. O., Rich, K. M., Boden, L. A., Moreno-Switt, A. I., Caipo, M. L., Zimin-Veselkoff, N., Alateeqi, A. M., \& Baltenweck, I. (2020). The covid-19 pandemic and global food security. Frontiers in Veterinary Science, 7(November), 1-8. https://doi.org/10.3389/fvets.2020.578508

Moorthy, S. N., \& Ramanujam, T. (1986). Variation in properties of starch in cassava varieties in relation to age of the crop. Starch - Stärke, 38(2), 58-61. https://doi.org/10.1002/star.19860380206

Parwiyanti, Pambayun, R., \& Charles. (2012). Sifat fisiko-kimia dan organoleptik "beras aruk" pada metode pengupasan dan periode perendaman yang berbeda. Seminar Nasional Fakultas Pertanian Universitas Sebelas Maret Surakarta, 1-10. https://onesearch.id/Record/IOS4554.2703

Pasqual, J., Padilla, E., \& Jadotte, E. (2013). Technical note: Equivalence of different profitability criteria with the net present value. International Journal of Production Economics, 142(1), $205-210$. https://doi.org/10.1016/j.ijpe.2012.11.007

Patriawan, W., Geo, L., \& Zani, M. (2018). Analsis kelayakan finansial usaha pengolahan sagu di Kelurahan Labibia Kecamatan Mandongakota Kendari. Jurnal Agribisnis Dan Ilmu Sosial Ekonomi Pertanian, 3(3), 54-58.

PH, L., Suwoso, R., Febrianto, T., Kushindarto, D., \& Aziz, F. (2020). Dampak Pandemi Covid-19 bagi Perekonomian Masyarakat Desa. Indonesian Journal of Nursing and Health Sciences, 1(1), 37-48. Retrieved from http://jurnal.globalhealthsciencegroup.com/index.php/IJNHS/article/view/225

Purnomo, R. A., Riawan, \& Sugianto, L. O. (2017). Studi Kelayan Bisnis. In Jurnal Universitas Muhammadiyah Ponorogo (1st ed.). Unmuh Ponorogo Press.

Puspitorini, P., Pitaloka, D., \& Kurniastuti, T. (2016). Uji daya hasil ubi kayu (Manihot esculenta Crantz) varietas uj5 pada berbagai umur panen. VIABEL: Jurnal IImiah IImu-IImu Pertanian, 10(1), 63-70.

Rahaman, M., \& Khatun, R. (2021). Socio-economic profile, challenges, and emergency assistance during the covid-19 lockdown: a case study on household industry workers in. IMCC Journal of Science, 82-93. https://myjournal.imcc.edu.ph/publication/volume-1-issue-1-2021/household-industry-workers-in-india-covid19lockdown/

Saini, H., Halid, A., \& Indriani, R. (2021). An analysis of financial feasibility of emping jagung business at a small mediumscale industry (LM3 IKM) of pondok pesantren Salafiyah Syafi'iyah In Banuroja Randangan Pohuwato. Jurnal Riset Dan Pengembangan IImu Pengetahuan, 06, 90-101. http://ejurnal.pps.ung.ac.id/index.php/JPS/article/view/589

Setiati, D. (2008). Makanan tradisional masyarakat Bangka Belitung (S. Rohana (ed.)). Departemen Kebudayaan dan Pariwisata Balai Pelestarian Sejarah dan Nilai Tradisional Tanjungpinang.

Smith-Daniels, D. E., \& Aquilano, N. J. (1987). Using a late-start resource-constrained project schedule to improve project net present value. Decision Sciences, 18(4), 617-630. https://doi.org/10.1111/j.1540-5915.1987.tb01550.x

Subhan, M., Rodika, \& Kurniawan, Z. (2018). Rancang bangun mesin mesin pencetak beras analog sebagai pangan lokal Daerah Bangka. Seminar Nasional Sains Dan Teknologi 2018, 1-5.

Sugiarti. (2018). Pengaruh biaya bahan baku dan biaya tenaga kerja langsung terhadap penjualan bersih pada PT Mustika Ratu Tbk. Jurnal Akrab Juara, 3(3), 10-21. http://akrabjuara.com/index.php/akrabjuara/article/view/337/266

Suryani, E. (2021). Analisis dampak covid-19 terhadap umkm (studi kasus:home industri klepon di Kota Baru Driyorejo). 
Jurnal Inovasi Penelitian, 1(8), 1-4. https://doi.org/https://doi.org/10.47492/jip.v1i8.272

Susilawati. (2010). Karakteristik sifat fisik dan kimia ubi kayu (Manihot esculenta) berdasarkan lokasi penanaman dan umur panen berbeda. Jurnal Teknologi Industri Dan Hasil Pertanian, 13(2), 59-72.

Syafril, M., \& Fidhiani, D. D. (2020). Kelayakan finansial usaha pengolahan terasi udang rebon di kelurahan Bontang Kuala kota Bontang provinsi Kalimantan Timur. Agromix, 11(1), 33-48. https://doi.org/10.35891/agx.v11i1.1897

Tung, Y.-K. (1992). should be taken in that probability distributions of economic criteria are the essentially required information. Several studies have employed a probabilistic approach to B / C analysis of water resource projects . The probability distributions used for. Journal of Water Resources Planning and Managemen, 118(2), 133-150. https://doi.org/10.1061/(asce)0733-9496(1992)118:2(133)

Xiao, H. W., \& Mujumdar, A. S. (2020). Importance of drying in support of human welfare. Drying Technology, 38(12), 1542-1543. https://doi.org/10.1080/07373937.2019.1686476

Yeo, S. F., Khoo, Y. H., Tan, C. L., \& Lim, K. B. (2020). Product packaging: Impact on customers' purchase intention. International Journal of Business and Society, 21(2), 857-864. https://doi.org/10.33736/ijbs.3298.2020

Yudi Garnida, D. (2014). Pengaruh sumber protein dan konsentrasinya terhadap karakteristik beras aruk. Pasundan Food Technology Journal, 1(1), 14-19. http://repository.unpas.ac.id/48216/ 